SPORTIVE: Journal of Physical Education, Sport and Recreation
Volume 1 Nomor 2 Maret 2018
e-ISSN: 2597-7016 dan p-ISSN: 2595-4055
$\begin{aligned} & \text { @) (1) This work is licensed under a Creative Commons Attribution } \\ & \text { 4.0 International License }\end{aligned}$

\title{
Hubungan Antara Panjang Tungkai Dan Daya Ledak Tungkai Dengan Kemampuan Lompat Jauh Siswa SMP Negeri 1 Balusu
}

\section{Hasbunallah $^{1}$}

\section{Keywords :}

Panjang Tungkai, Daya

Ledak Tungkai,

Kemampuan Lompat

\section{Corespondensi Author}

${ }^{1}$ Universitas Negeri Makassar, Email:

hasbunallahas@yahoo.com

\author{
Article History \\ Received: 30-06-2018; \\ Reviewed: 10-07-2018; \\ Accepted: 15-17-2018; \\ Published: 23-07-2018
}

\begin{abstract}
Penelitian ini bertujuan untuk mengetahui apakah ada hubungan panjang tungkai dan daya ledak tungkai dengan kemampuan lompat jauh. Penelitian ini termasuk penelitian deskriptif dengan dua variabel bebas, yaitu, panjang tungkai dan daya ledak tungkai dan satu variabel terikat yaitu kemampuan lompat jauh. Populasi penelitian ini adalah SMP Negeri 1 Balusu. Secara random sampling di pilih sample sebanyak 60 siswa. Teknik pengumpulan data menggunakan tes pengukuran panjang tungkai dan daya ledak tungkai dengan kemampuan lompat jauh. Teknik analisis data yang digunakan adalah analisis korelasi tunggal dan korelasi ganda yang di analisis dengan menggunakan fasilitas computer melalui program SPSS. Berdasarkan analisis data diperoleh hasil : (1) Ada hubungan yang signifikan antara panjang tungkai dengan kemampuan lompat jauh, diperoleh nilai $r$ hitung $($ ro $)=.919$ $(P<0.05)$. (2) Ada hubungan yang signifikan antara daya ledak tungkai dengan kemampuan lompat jauh, diperoleh nilai $r$ hitung (ro) $=.920(P<0.05)$. (3) Ada hubungan yang signifikan antara panjang tungkai dan daya ledak tungkai dengan kemampuan lompat jauh, diperoleh nilai $R$ hitung (Ro) $=.930(P<0.05)$.
\end{abstract}

Kata Kunci: Panjang Tungkai, Daya Ledak Tungkai, Kemampuan Lompat 


\section{PENDAHULUAN}

Pendidikan jasmani dan olahraga dapat membentuk generasi muda yang lebih baik dan potensial dlam rangka pembangunan manusia seutuhnya, maka dari itu pemerintah telah menggalakkan olahraga dengan cara memasyarakatkan olahraga dan mengolahragakan masyarakat. Disamping penyebarluasan kegiatan olahraga sudah merata diseluruh pelosok tanah air, olahraga juga mudah dimasukkan kedalam kurikulum sekolah mulai dari Taman Kanak-kanak sampai ketingkat sekolah lanjutan atas.

Pembinaan olahraga di Indonesia selain untuk membentuk manusia Indonesia yang sehat fisik dan mental, juga menanam dan memupuk kejujuran, sportifitas.

Dengan melakukan olahraga dapat menanam, memupuk dan mengembangkan sikap mental, kejujuran, keberanian, daya juang dan semangat bersaing, jiwa sportivitas yang didalamnya terkandung nilai-nilai pendorong generasi muda sebagai taman bangsa yang mampu tumbuh menjadi generasi yang baik dan berjiwa sehat dalam rangka mengisi kemerdekaan bangsa Indonesia.

Pernyataan diatas mengandung pengertian bahwa olahraga merupakan aspek kegiatan yang harus dikembangkan dalam usaha pembinaan bangsa, sehimgga olahraga diharapkan akan menjadi kebutuhan hidup bagi segenap bangsa Indonesia.

Usaha pembinaan olahraga yang dimulai pada tingkat sekolah sangat tepat, karena sekolah merupakan tempat dimana anak didik dibimbing dan dilatih agar dapat memiliki mental fisik yang kuat, terampil, cekatan dan lincah.

Usaha pembinaan olahraga di sekolah merupakan hal yang penting bila ingin dicapai prestasi yang tinggi dimasa mendatang. Demikian pula yang dikatakan oleh Soekarman (1997 : 4) ketahanan atau stamina harus dicapai puncaknya pada masa remaja, dan untuk itu harus dilakukan latihan bertahap sejak usia 9 tahun sampai dewasa.

Program pembinaan olahraga harus mantap dan berkesinambungan, sebagaimana yang dikemukakan oleh Soegiyono (1988: 13) bahwa : "Pembinaan dimulai sejak usia dini tersusun secara sistimatik, yang dimulai dari pemassalan, pembibitan dan pembinaan prestasi yang berbentuk piramida berjenjang dari bawah keatas". Bentuk program pembinaan yang serupa dijelaskan oleh Imam Suyudi (1984 : 7-8) bahwa : Program pendidikan jasmani disekolah tidak terlepas dari program pembinaan olahraga yang berjenjang dari bawah keatas, dimulai dari program pelajaran (instruksional), program kegiatan diluar jam sekolah (instramural), kegiatan antar sekolah (intersemelastic), kegiatan tingkat nasional (POPSI) dan kegiatan tingkat internasional.

Dengan demikian sasaran pemassalan, pembibitan, menuju kepembinaan prestasi adalah sekolah yang dimulai dari sekolah dasar sampai sekolah lanjutan atas.

Salah satu tujuan pendidikan jasmani disekolah adalah untuk meningkatkan kesegaran jasmani (physical fitness) murid. Kesegaran jasmani merupakan dasar untuk Moeloek (1984 : 2) bahwa : Kesegaran jasmani merupakan hal kompleks karena didalamnya terdapat aspek fisik, terdiri dari daya tahan, kekutatan, kecepatan, tenaga ledak otot, ketangkasan, kelentukan, keseimbangan, kecepatan reaksi dan koordinasi.

Aspek-aspek tersebut yang sangat berguna dan perberan dalam pembinaan salah satu cabang olahraga menuju prestasi, salah satunya yaitu cabang olahraga atletik khususnya nomor lompat jauh.

Cabang olahraga atletik merupakan salah satu cabang olahraga yang penting karena didalam mengandung nilai-nilai edukatif (pendidikan), dan hal itu memegang peranan penting dalam mengembangkan dan meningkatkan restasi yang optimal cabangcabang olahraga lain.

Nomor-nomor perlombaan pada cabang olahraga atletik merupakan gerak dasar alamiah seperti beralari, berjalan, melompat dan melempar. Salah satu nomor yang sering diperlombakan yaitu nomor lompat yang terdiri lompat jauh, lompat tinggi, lompat tinggi galah dan lompat jangkit. Lompat jauh merupakan salah satu jenis perlombaan yang mempunyai tujuan yaitu untuk mencapai suatu jarak horizontal maksimal.

Untuk mencapai prestasi yang maksimal dalam cabang olahraga atletik khususnya nomor lompat jauh, harus didukung oleh berbagai kemampuan fisik dan unsur potensi bilogis. Kemampuan daya ledak tungkai dan panjang tungkai merupakan salah satu kemampuan fisik dan potensi biologis yang sangat berperan untuk mencapai jarak lompatan yang maksimal. 
Kemampuan daya ledak tungkai sangat penting dalam setiap aktivitas pada cabang olahraga terutama yang mengharuskan atlet untuk bertolak dengan kaki. Jadi dapat dikatakan bahwa daya ledak tungkai sangat menentukan hasil lompatan dalam lompat jauh. Menurut Dick dkk, (1978) yang dikutip oleh Harsono (1988 : 199) bahwa : "Tenaga eksplosif penting untuk cabang-cabang olahraga yang eksplosif seperti sprint lari gawang, nomor-nomor lompat dalam atletik. Oleh karena itu dalam tenaga eksplosif mencakup dua unsure fisik yang terpadu dalam suatu pola gerak yaitu kekuatan dan kecepatan.

Pada dasarnya seseorang yang mempunyai tungkai yang panjang akan dapat mencapai jarak lompatan yang lebih jauh dibandingkan dengan orang yang mempunya tungkai yang pendek, hal ini dikarenakan tungkai yang panjang dapat melakukan ayunan kaki yang lebih baik pada saat melakukan gerakan jangkauan kaki lebih jauh pada saat mendarat. Dari segi fisiologi dikemukakan oleh M. Anwar Pasau (1998 : 81) bahwa : Orang yang mempunyai fisik yang tinggi dan besar rata-rata mempunyai kemampuan fisik seperti kekuatan, kecepatan, daya tahan jantung paruparu daya tahan otot dan lain-lain, lebih baik dari pada orang yang bertubuh kecil dan pendek.

Berdasarkan pendapat diatas
menunjukkan bahwa kemampuan daya ledak tungkai kearah horizontal yang dimiliki oleh seorang pelompat harus ditunjang dengan tungkai yang panjang. Karena tungkai yang panjang disertai adanya kemampuan dari tungkai untuk mengarahkan kekuata dan kecepatan diharapkan dapat menunjangntercapainya jarak lompatan yang maksimal.

Berdasarkan penjelasan diatas, maka diketahui bahwa kemampuan daya ledak tungkai dan panjang tungkai yang dimaksud dalam penelitian ini adalah kemampuan yang berkembang secara alamiah yang belum mendapat pengembangan dan latihan secara intensif dan terprogram, yaitu seperti pada prestasi lompat jauh siswa-siswa SMP Negeri 1 Balusu.

Lompat jauh sbenarnya terdiri dari beberapa unsur-unsur pokok meliputi lari awalan, tumpuan, melayang dan mendarat. Keempat unsur ini merupakan satu kesatuan yaitu suatu gerakan uruan melompat yang tidak terputus-putus. Dengan demikian dapat dipahami bahwa hasil lompatan itu dipengaruhi oleh kecepatan lari awalan, kekuatan kaki tumpu dan koordinasi gerak waktu melayang dan mendarat.

a. Lari awalan

Kecepatan dan ketepatan dalam lari awalan sangat memperngaruhi hasil lompatan. Ini berarti kecepatan lari awalan merupakan keharusan untuk mencapai hasil yang optmal. Seperti yang dikemukakan oleh Rorinpandey dalam Aip Syarifuddin (1992 : 68) bahwa "Pelompat itu sama cepatnya dengan sprinter. Tanpa kecepatan, seorang atlet lompat jauh tidak mungkin untuk mencapai hasil yang sebaikbaiknya".

Menurut Yusuf Adisasmita (1992 : 67) yang mengatakan bahwa untuk melakukan lari dengan baik perlu memperhatikan hal-hal sebagai berikut :

a) Jarak lari awalan tergantung pada tiap pelompat.

b) Jarak lari awalan harus cukup jauh untuk mencapai kecepatn maksimal dan untuk mendapatkan momentum yang besar.

c) Kecepatan lari awalan dan irama langkah harus rata

d) Pada langkah terakhir, pikiran dipusatkan untuk melompat keatas setinggi-tingginya.

e) Langkah terakhir diperkecil agar dapat menolak keatas dengan sempurna

f) Sikap lari sama seperti lari jarak pendek

b. Tumpuan

Tumpuan atau tolakan adalah perpindahan yang sangat cepat antara lari awalan dan melayang. Aip Syarifuddin (1992 : 69) menyatakan bahwa : Tolaka yang perubahan atau perpindahan gerakan horizontal kegerakan vertikal yang dilakukan secara cepat dimana sebelumnya sipelompat suda mempersiapkan diri untuk melakukan tolakan sekuat-kuatnya pada langkah yang terakhir, sehingga seluruh tubuh terangkat keatas melayang keudara.

Jadi tumpuan disini dapat juga dikatakan sebagai satu gerakan yang menggabungkan antara keccepatan horizontal dan kecepatan vertikal yang didukung oleh kecepatan dan kekuatan tungkai dalam mengubah kedua gerakan tersebut sehingga dapat menghasilkan jarak lompatan yang maksimal.

Pada waktu menolak, seharusnya badan sudah harus condong kedepan, titik berat badan harus terletak agak didepan untuk sumber tenaga 
yaitu kaki tumpu pada saat pelompat menumpu. Letak titik berat badan ditentukan oleh panjang langkah terakhir sebelum melompat. Kalau langkah itu terlalu panjang, titik berat badan akan terletak dibelakang sumber tenaga. Jika terjadi demikian pelompat akan sulit mencapai ketinggian yang diinginkan atau sudut lompatan yang ideal sehingga berpengaruh terhadap hasil lompatan. Bila titik berat badan itu terletak tepat diatas kaki tumpu, pelompat itu hanya akan melompat tinggi keatas. Sedangkan yang dibutuhkan adalah lompatan keatas dan kedepan. Ketinggian lompatan sangat penting karena dapat membuat tubuh kita agak lama melayang diudara.

c. Melayang

Sikap badan diudara (melayang) sangat erat hubungannya kecepatan awal dan kekuatan tolakan, badan sipelompat dipengaruhi oleh suatu kekuatan yang disebut gaya tarik bumi. Gaya titik bumi itu bertitik terletak pada suatu titik yang disebut titik berat badan.

R. Abd. Askar Setiakusumah (1956) dalam Aip Syarifuddin (1992 : 92) mengatakan bahwa : "Sewaktu melayang diudara sipelompat tidak dapat mengubah lintasan titikberat badannya kecuali ada gaya lain dari luar yang mempengaruhinya".

Untuk memperoleh ketinggian sehingga dapat melayang lebih tinggi, dibutuhkan kecepatan dan kekuatan dalam bertumpu saat lepas dari balok tumpuan, badan harus dalam keadaan tidak kaku, kemudian melakukan gerakan-gerakan sikap tubuh untuk menjaga keseimbangan dan untuk memungkinkan pendaratan yang lebih sempurna. Gerakan sikap tubuh diudara pada saat melayang, inilah yang biasa disebut gaya lopat jauh. Waktu melayang diudara dapat dilakukan berbagai gaya lompatan sesuai kemampuan atau keterampilan dari masing-masing pelompat.

d. Mendarat

Sikap mendarat pada lompat jauh, baik untuk lompat jauh gaya jongkok, gaya menggantung maupun gaya berjalan diudara adalah sama. Pada saat mendarat, pelompat harus berusaha menjulurkan kedua kakinya kedepan dengan titik kehilangan keseimbangan badannya. Pada saat tersebut kita terasa akan jatuh kebelakang. Untuk mencegahnya diusahakan titik berat badan dibawa kedepan dengan jalan membungkukkan badan hingga dada dan lutut hampir merapat dibantu oleh uluran tangan kedepan. Pada saat pendaratan lutut dibengkokkan sehingga memungkinkan suatu momentum membawa titik berat badan kedepan. Pendaratan dilakukan dengan tumit terlebih dahulu menyentuh tanah.

Dengan memperhatikan beberapa penjelasan diatas yang terdiri dari empat tahap dalam lompat jauh, ada beberapa komponen yang sangat mempengaruhi tercapainya prestasi yang maksimal dari seorang pelompat jauh yaitu kecepatan dan kekuatan dalam melakukan lari awalan atau yang biasa juga disebut dengan daya ledak kearah horizontal yang disertai dengan kecepatan dan kekuatan pada saat melakukan tolakan atau disebut juga dengan daya ledak kearah vertikal.

Tungkai merupakan bagian tubuh manusia yang termasuk dalam bidang gerak bawah (inferior), yang meliputi pinggul, paha, betis dan kaki. Panjang tungkai dapat diketahui melalui hasil pengukuran mulai dari lantai sampai akhir coluim spinal. Menurut Barry L. Johnson (1986 : 191) mengemukakan bahwa : Leg length, measured from end of the spinal colum to the floer. Also taken from greater trichanter to floor sometimes the difference between sitting and standing heights is used.

Pendapat diatas secara bebas dapat diterjemahkan bahwa panjang tungkai diukur dari akhir colum spinal sampai kelantai juga dapat dilakukan dari trochanter mayor sampai kelantai.

Pada beberapa cabang olahraga pengaruh panjang tungkai sangat berperan dalam pencapaian prestasi yang lebih baik. Karena orang yang mempunyai tungkai yang panjang diharapkan dapat mencapai jarak lompatan yang lebih jauh dibandingkan dengan orang yang mempunyai tungkai pendek, karena tungkai yang panjang dapat melakukan ayunan kaki yang lebih baik pada saat bertolak serta jangkauan yang lebih jauh saat mendarat pada lompat jauh.

Menurut Rorimpandey (1960 : 146) mengemukakan bahwa : Orang yang panjang tungkainya tentu lebih tinggi lompatannya dari pada orang yang lebih pendek tungkainya, artinya kalau kedua-duanya itu berada dalam keadan yang sama, artinya kesehatan yang sama, kecakapan teknik yang sama serta sifat-sifat kerohanian yang sama.

Dari pendapat diatas yang mengemukakan bahwa orang yang mempunyai tungkai yang panjang tentunya dapat melakukan lompatan yang lebih baik dibandingkan dengan orang yang tungkainya pendek, artinya dalam keadaan yang sama. Seperti halnya dengan yang 
dikemukakan oleh M. Anwar Pasau (1998 : 81) bahwa : Orang yang mempunyai fisik yang tinggi dan besar rata-rata mempunyai kemampuan fisik seperti kekuatan, kecepatan, daya tahan jantung paru-paru daya tahan otot dan lain-lain, lebih baik dari pada orang yang bertubuh kecil dan pendek.

Berdasarkan pendapat diatas bahwa fisik yang tinggi tentu akan mempunyai tungkai yang panjang dan diharapkan orang yang mempunyai tungkai yang panjang dapat mencapai prestasi yang lebih baik, karena fisik yang tinggi dan besar rata-rata mempunyai kekuatan, kecepatan, daya tahan otot dan sebagainya, kesemuanya berperan dalam peningkatan prestasi lompat jauh.

Daya ledak tungkai biasa juga disebut dengan istilah tenaga eksplosif yang sangat dibutuhkan dalam berbagai cabang olahraga, apalagi kalau orang itu menntut untuk aktivitas yang berat dan cepat atau kegiatan itu harus dilakukan dalam waktu sesingkat mungkin dengan beban berat. Untuk mampu melaksanakan aktivitas seperti itu dilakukan perpaduan antara kekuatan dan kecepatan otot yang dikerahkan secara bersama-sama dalam mengatasi tahanan beban dalam waktu yang relatif singkat.

Dick yang diterjemahkan oleh Harsono (1988 : 199) mengemukakan bahwa : Daya ledak tungkai adalah kemampuan otot untuk mengatasi tahanan dengan kontraksi yang sangat cepat, daya ledak tungkai sangat penting untuk cabang-cabang olahraga yang eksplosif seperti sprint, lari gawang, nomor-nomor lempar dan lompat dalam atletik.

Selanjutnya Mohammad Sajoto (1988 : 58) mengemukakan bahwa : Daya ledak tungkai adalah kemampuan seseorang untuk melakukan kekuatan maksimum, dengan usahanya yang dikerahkan dalam waktu sependek-pendeknya. Dalam hal ini diktakan bahwa daya ledak otot atau daya ledak tungkai $=$ kekuatan atau force $\mathrm{x}$ kecepatan atau velocity.

Dari kedua pendapat tersebut diatas menyebutkan dua unsur yang penting dalam daya ledak tungkai yaitu kekuatan otot dan kecepatan otot dalam mengerahkan tenaga maksimal untuk mengatasi tahanan, sehingga dengan demikian dapat disimpulkan batasan daya ledak tungkai sebagai berikut : daya ledak tungkai adalah kemampuan otot untuk mengerahkan kekuatan maksimal dalam waktu yang sangat cepat.
Secara umum kemampuan daya ledak tungkai dikenal sebagai salah satu komponen fisik yang sangat dibutuhkan dalam berbagai cabang olahraga, namun kemampuan daya ledak tungkai bukan unsur penentu satu-satunya dalam melakukan aktivitas olahraga agar nampak terampil dalam mencapai prestasi puncak, akan tetapi saling menunjang satu sama lain dari berbagai unsur potensi fisik termasuk pengaruh panjang tungkai.

Kekuatan tetap merupakan dasar untuk menentukan daya ledak tungkai. Sebelum latihan daya ledak tungkai, orang harus sudah memiliki sesuatu tingkat kekuatan otot yang baik. Seperti yang dikemukakan oleh Abdul Kadir Ateng (1992 : 140) bahwa : "Tenaga otot adalah kemampuan untuk melepaskan kekuatan otot secara maksimal dalam waktu yang sangat singkat".

Maka dapat dikatakan bahwa daya ledak tungkai lebih dibutuhkan dalam semua cabang olahraga termasuk cabang atletik khususnya nomor lompat jauh. Karena untuk menampilkan pola gerak olahraga daya ledak tungkai diperlukan unsur kekuatan maupun kecepatan yang dikombinasikan dalam suatu gerakan secara terpadu.

Dari pendapat diatas, dua unsur penting dalam dalam tenaga eksplosif atau daya ledak tungkai adalah kekuatan dan kecepatan otot dalam mengerahkan tenaga maksimal untuk mengatasi tahanan. Dengan demikian dapat disimpulkan bahwa daya ledak tungkai adalah kemampuan otot untuk mengerahkan kekuatan maksimal dalam waktu yang sangat cepat.

\section{METODE}

Jenis penelitian ini adalah jenis deskriptif Regresi, jenis analisis data yaitu dengan cara menganilisis data kuantitatif yang diperjelas dari hasil penelitian berupa data dan informasi mengenai permasalahan yang dibahas. Adapun variabel penelitian yang ingin diteliti dalam penelitian ini terdiri atas Variabel bebas Panjang tungkai $\left(\mathrm{X}_{1}\right)$ dan Daya ledak tungkai $\left(\mathrm{X}_{2}\right)$ sedangkan Variabel terikatnya adalah kemampuan lompat jauh (Y)

populasi pada penelitian ini adalah seluruh siswa putri SMP Negeri 1 Balusu.Sampel yang diambil atau digunakan dalam penelitian ini berjumlah 60 orang siswa SMP Negeri 1 Balusu.

Teknik pengumpuilan data pada penelitian ini adalah pengukuran secara langsung Sehubungan dengan penelitian ini 
adalah jenis penelitian deskriptif, maka tidak dilakukan perlakuan pada sampel akan tetapi langsung di tes sesuai dengan data yang dibutuhkan penelitian ini yaitu data tentang panjang tungkai, kemampuan daya ledak tungkai, dan kemampuan lompat jauh. Data yang terkumpul melalui tes, masih merupakan data kasar. Data tersebut selanjutnya dianalisis dengan menggunakan uji statistik regresional dengan bantuan paket SPSS dalam komputer.

\section{HASIL DAN PEMBAHASAN}

Hasil analisis deskriftif setiap variabel penelitian ini dapat dilihat pada table 1 .

Tabel 1. Hasil analisis deskriftif panjang tungkai dan daya ledak otot tungkai dengan kemampuan lompat jauh .

\begin{tabular}{|c|c|c|c|c|c|}
\hline Nilai Statistik & $\mathrm{N}$ & Rataan & Range & Min & Max \\
\hline PT & 60 & 78.2000 & 15.00 & 70.00 & 85.00 \\
\hline DLT & 60 & 1.9200 & .47 & 1.70 & 2.17 \\
\hline KLJ & 60 & 4.0652 & .95 & 3.70 & 4.65 \\
\hline
\end{tabular}

Keterangan tabel 1 :
PT
: Panjang tungkai
DLT
: Daya ledak tungkai
KLJ
: Kemampuan lompat jauh

Dari tabel 1 diatas yang merupakan gambaran data panjang tungkai dan daya ledak otot tungkai dengan kemampuan lompat jauh dapat dikemukakan sebagai berikut :

1. Panjang tungkai, diperoleh rata-rata 78.2000 , data minimal 70.00 data maksimal 85.00 rentang 15.00

2. Daya ledak otot tungkai, diperoleh rata-rata 1.9200 data minimal 1.70 data maksimal 2.17 rentang .47

3. Kemampuan lompat jauh, diperoleh rata-rata 4.0652 data minimal 3.70, data maksimal 4.65 , rentang .95

Hasil analisis data deskriftif tersebut diatas baru merupakan gambaran umum data panjang tungkai dan daya ledak otot tungkai dengan kemampuan lompat jauh. Data tersebut diatas belum menggambarkan bagaimana keterkaitan atau saling hubungan antara variabel penelitian tersebut.

a. Korelasi Panjang tungkai dengan kemampuan lompat jauh.

Untuk mengetahui keeratan hubungan Panjang tungkai dengan kemampuan lompat jauh dilakukan analisis korelasi pearson .

Rangkuman Hasil analisisnya dapat dilihat pada tabel 3

Tabel 3. Rangkuman hasil analisis korelasi Panjang tungkai dengan kemampuan lompat jauh .

\begin{tabular}{|c|c|c|c|}
\hline Variabel & $\mathrm{r}$ & $\mathrm{p}$ & Keterangan \\
\hline PT (X1) & 0.919 & 0.000 & Signifikan \\
\hline
\end{tabular}

Berdasarkan tabel 3 diatas terlihat bahwa hasil perhitungan korelasi pearson, diperoleh nilai korelasi hitung $(\mathrm{r})=0.919(\mathrm{P}<0.05)$, berarti ada hubungan yang signifikan antara Panjang tungkai dengan kemampuan lompat jauh SMP Negeri 1 Balusu. Dalam hal ini apabila siswa memiliki Panjang tungkai yang baik maka akan diikuti dengan kemampuan lompat jauh dengan baik pula. 


\section{b. Korelasi Daya ledak otot tungkai dengan kemampuan lompat jauh.}

Untuk mengetahui keeratan hubungan

Daya ledak otot tungkai dengan kemampuan lompat jauh dilakukan analisis korelasi pearson

Rangkuman Hasil analisisnya dapat dilihat pada tabel 4

Tabel 4. Rangkuman hasil analisis korelasi Daya ledak otot tungkai dengan kemampuan lompat jauh .

\begin{tabular}{|c|c|c|c|}
\hline Variabel & $\mathrm{r}$ & $\mathrm{P}$ & Keterangan \\
\hline $\begin{array}{c}\text { DLT (X2) } \\
\text { KMB (Y) }\end{array}$ & .920 & 0.000 & Signifikan \\
\hline
\end{tabular}

Berdasarkan tabel 4 diatas terlihat bahwa hasil perhitungan korelasi pearson, diperoleh nilai korelasi hitung $(\mathrm{r})=.920(\mathrm{P}<$ $0.05)$, berarti ada hubungan yang signifikan antara Daya ledak otot tungkai dengan kemampuan lompat jauh SMP Negeri 1 Balusu. Dalam hal ini apabila siswa memiliki Daya ledak otot tungkai yang baik maka akan diikuti dengan kemampuan lompat jauh dengan baik pula

c. Korelasi ganda panjang tungkai dan daya ledak otot tungkai dengan kemampuan lompat jauh .

Untuk mengetahui keeratan hubungan panjang tungkai dan daya ledak tungkai secara bersama-sama dengan kemampuan lompat jauh dilakukan analisis korelasi ganda.

Rangkuman Hasil analisisnya dapat dilihat pada tabel 5.

Tabel 5 Rangkuman hasil analisis korelasi panjang tungkai dan daya ledak otot tungkai dengan kemampuan lompat jauh.

\begin{tabular}{|c|c|c|c|}
\hline Variabel & $\mathrm{R}_{\mathrm{o}}$ & $\mathrm{P}$ & Keterangan \\
\hline $\begin{array}{c}\text { PT (X1),DLT } \\
\text { (X2) } \\
\text { KMB (Y) }\end{array}$ & .930 & 0.000 & signifikan \\
\hline
\end{tabular}

Berdasarkan tabel 5 diatas terlihat bahwa hasil perhitungan korelasi ganda, diperoleh nilai korelasi ganda hitung $\left(\mathrm{R}_{\mathrm{o}}\right)=.930$ $(\mathrm{P}<0.05)$, berarti ada hubungan yang signifikan antara panjang tungkai dan daya ledak otot tungkai dengan kemampuan lompat jauh SMP Negeri 1 Balusu. Dalam hal ini apabila siswa memiliki panjang tungkai dan daya ledak otot tungkai yang baik maka akan diikuti dengan kemampuan lompat jauh dengan baik pula. Hasil analisis data melalui tehnik statistik diperlukan pembahasan teoritis yang bersandar pada teori-teori dan kerangka berpikir yang mendasari penelitian ini.

1. Hasil uji hipotesis pertama : Ada hubungan yang signifikan Panjang tungkai dengan kemampuan lompat jauh SMP Negeri 1 Balusu. Hasil analisis statistic menunjukkan bahwa ada hubungan yang signifikan antara Panjang tungkai dengan kemampuan lompat jauh SMP Negeri 1 Balusu. Apabila hasil penelitian ini dikaitkan dengan teori dan kerangka berpikir yang mendasarinya, maka pada dasarnya hasil penelitian ini mendukung dan memperkuat teori dan hasil-hasil penelitian terdahulu yang sudah ada. Jika Panjang tungkai dianalisis dari segi fisik yang terlibat didalamnya, maka unsur Panjang tungkai mendukung kemampuan lompat jauh SMP Negeri 1 Balusu. Seorang siswa memiliki Panjang tungkai yang baik akan dengan sendirinya mampu melakukan lompatan dengan baik pula. Dalam hal ini, Panjang tungkai akan memberikan sumbangan yang berarti dalam melakukan lompatan. Oleh karena itu, dapat disimpulkan bahwa untuk menghasilkan kemampuan lompat jauh secara maksimal, maka Panjang tungkai sangat memegang peranan penting, yaitu terjadinya perpaduan antara kecepatan dan Panjang tungkai dalam berlari dengan idikator irama dan frekuensi langkah yang cepat serta Panjang ayunan kaki dalam melangkah.

2. Hasil uji hipotesis Kedua : Ada hubungan yang signifikan Daya ledak otot tungkai dengan kemampuan lompat jauh SMP Negeri 1 Balusu. Hasil analisis statistic menunjukkan bahwa ada hubungan yang signifikan antara Daya ledak otot tungkai dengan kemampuan lompat jauh SMP Negeri 1 Balusu. Apabila hasil penelitian ini dikaitkan dengan teori dan kerangka berpikir yang mendasarinya, maka pada dasarnya hasil penelitian ini mendukung dan memperkuat teori dan hasil-hasil 
penelitian terdahulu yang sudah ada. Jika Daya ledak otot tungkai dianalisis dari segi fisik yang terlibat didalamnya, maka unsur Daya ledak otot tungkai mendukung kemampuan lompat jauh SMP Negeri 1 Balusu. Seorang siswa memiliki Daya ledak otot tungkai yang baik akan dengan sendirinya mampu melakukan lompatan dengan baik pula. Analisa peranan dari Daya ledak otot tungkai sangat nampak ketika orang melakukan dorongan pada saat akan melakukan lompatan.

3. Hasil uji hipotesis Ketiga : Ada hubungan yang signifikan panjang tungkai dan daya ledak otot tungkai dengan kemampuan lompat jauh SMP Negeri 1 Balusu. Hasil analisis statistic menunjukkan bahwa ada hubungan yang signifikan antara panjang tungkai dan daya ledak otot tungkai dengan kemampuan lompat jauh SMP Negeri 1 Balusu. Apabila hasil penelitian ini dikaitkan dengan teori dan kerangka berpikir yang mendasarinya, maka pada dasarnya hasil penelitian ini mendukung dan memperkuat teori dan hasil-hasil penelitian terdahulu yang sudah ada. Apabila siswa memiliki panjang tungkai dan daya ledak otot tungkai yang baik akan mampu melakukan lompatan yang lebih jauh.

\section{Kesimpulan dan Saran}

Penelitian tentang panjang tungkai dan daya ledak otot tungkai dengan kemampuan lompat jauh dapat disimpulkan sebagai berikut :

1. Ada hubungan yang signifikan antara panjang tungkai dengan kemampuan lompat jauh SMP Negeri 1 Balusu.

2. Ada hubungan yang signifikan antara daya ledak otot tungkai dengan kemampuan lompat jauh SMP Negeri 1 Balusu.

3. Ada hubungan yang signifikan antara panjang tungkai dan daya ledak otot tungkai dengan kemampuan lompat jauh SMP Negeri 1 Balusu.

Berdasarkan kesimpulan penelitian tersebut diatas, maka dapat disarankan sebagai berikut

1. Dalam memilih atlet yang akan di latih sebaiknya, guru pendidikan jasmani dan pelatih selalu memperhatikan unsur komponen fisik yang ikut berperan seperti panjang tungkai dan daya ledak otot tungkai.

2. Kepada rekan-rekan peneliti di sarankan untuk melakukan penelitian lanjutan dengan cakupan yang luas dan melihat kemungkinan adanya variabel lain yang juga memiliki kontribusi atau pengaruh yang positif terhadap pembinaan olahraga atletik.

3. Kemampuan lompat jauh sebagai salah satu opsi variabel dalam penelitian dengan pertimbangan pendekatan karekteristik anak sekolah perlu di informasikan secara meluas kepada guru pendidikan jasmani agar terjadi kesepahaman dalam pemberian materi sajian terutama pada cabang olah raga atletik.

\section{DAFTAR PUSTAKA}

Adisasmita, Yusuf, 1992. Olahraga pilihan atletik. Dirjen Dikti Jakarta.

Ateng, Abd. Kadir. 1992. Asas dan landasan pendidikan jasmani. Jakarta : Dirjen Dikti Depdikbud.

Barrow, M. Harold. Mc. GEE, Rasemary. A proctical approach to measurement in physical education. Philadelphia : Lea \& Febiger.

Barry, L. Johnson. 1986. Practical measurement for evaluation in physical education. Mnaesota : Burgess sounders college publishing.

Fox, E. L., Borws, R. W., Foss, M. L. 1988. The psiological basic of physical education and atletics. New York : Sounders college publishing.

Furchan, Arief. 1982. Pengantar dalam pendidikan. Surabaya : Usaha Nasional.

Hadi, Sutrisno. 1994. Metodologi research. Yogyakarta : Andi Offset.

$$
\text { 1995. Statistik jilid }
$$

II. Yogyakarta : Andi Offset. 
Harsono. 1988. Coaching dan aspek-aspek psikologi dalam coaching. Jakarta : P2LPTK Depdikbud.

IAAF, LEVEL I 1994. Teknik-teknik atletik dan tahap-tahap mengajarkan. Jakarta : PASI.

Imam Suyudi. 1994. Aspek pendidikan dalam olahraga. Jakarta Pusat Ilmu Olahraga KONI Pusat.

Jansen, C. R., Gordon, W. I and Bengester, BL. 1983. Aplied kinesiology and biomekanic. New York : Mc. Graw Hill Book Company.

Moeloek, Dangsina. 1984. Dasar fisiologi kesegaran jasmani dan latihan fisik dalam kesehatan dan olahraga. Jakarta : Fakultas Kedokteran UI.

Pasau, M. Anwar. 1998. Pertumbuhan dan perkembangan fisik. Ujung Pandang : FPOK IKIP Ujung Pandang.

Rani, Abd. Adib. 1993. Pembinaan prestasi olahraga. FPOK IKIP Ujung Pandang.

Rorimpandey, F. G. E. 1960. Lari, lompat, dan lempar. Jakarta : PT. Pembangunan.

Mochammad Sajoto. 1988. Pembinaan kondisi fisik dalam olahraga. Jakarta : Depdikbud Dirjen Dikti.

Sudjana. 1992. Teknik analisis regresi dan korelasi. Bandung : Tarsito.

Soekarman, R. 1997. Dasar olagraga untuk pembina, pelatih atletik. Jakarta : PT. Inti Idayu Press.

Sugiyono. 1988. Pelaksanaan pendidikan jasmani dan masalahnya. Makalah seminar nasional pengkajian teknologi olahraga. Jakarta : PPS IKIP Jakarta.

Sumosardjuno, S. 1986. Pengathuan praktis kesehatan dalam olahraga. Jakarta : PT. Gramedia Pustaka Utama.

Syarifuddin Aip. 1992. Atletik. Jakarta : P2TK Ditjen Dikti Depdikbud.

Willmoer. J. H. 1977. Atletic training and phisical fitness. Sidney : Allyn and Bacon Inc. 